\title{
Hubungan antara Karakteristik Petani dengan Motivasinya dalam Membudidayakan Tanaman Tebu (Kasus Kelompok Tani Dewi Ratih 1, Desa Maospati, Kecamatan Maospati, Kabupaten Magetan)
}

\author{
DIAN KURNIASIH, WAYAN SUDARTA, NYOMAN PARINING \\ Program Studi Agribisnis, Fakultas Pertanian, Universitas Udayana \\ Jl. PB. Sudirman Denpasar 80323 \\ Email: diankurniasih701@gmail.com \\ sudarta_wayan@ymail.com
}

\begin{abstract}
Correlation Between Farmer Characteristic With Their Motivation In Cultivate A Sugar Cane (In Case Of Dewi Ratih 1 Farmer Group At Maospati Village, Subdistrict Of Maospati, Magetan Regency)
\end{abstract}

Sugar cane plant plays an important role in meeting the sugar consumtion needs of society and industrial sector. In order to support the improvement of sugar cane plant production, the government should provide an input or direction that is needed by sugar cane farmers as a motivation for farmers to increase the production of sugar cane as a raw material for sugar. The characteristics of the farmers have become one of important factors that affect the farmer motivation in cultivation of sugar cane plant in farmer's group of Dewi Ratih 1, Maospati Village, Maospati Districts, Magetan Regency. Which is expected to be a reference for the government and the farmers in determine the policies and development strategies in order to make sugar cane farming can improve revenue and the welfare of the farmers. The purpose of this research is to identify the characteristics of the farmer, motivation of the farmers in cultivating sugar cane plant and determine the correlation between the farmers characteristics and the farmer motivation in cultivating sugar cane plant in farmer's group of Dewi Ratih 1, Maospati village, Maospati districts, Magetan regency. This sampling by using simple random method. Data analysis method that is used is descriptive analysis and spearman rank correlation coefficient test. The result of descriptive analysis shows that the farmers characteristics included in the low category, while the farmer motivation in cultivation of sugar cane plant included in the medium category. The result of spearman rank correlation analysis shows that the characteristics of the farmers who have a significant correlation with the motivation of the farmers is age, household income, vast of arable land, the number of household members, and farming experience.

Keywords: farmer characteristic, motivation, spearman rank correlation analysis, sugar cane plant 


\section{Pendahuluan}

\subsection{Latar Belakang}

Pengembangan industri gula mempunyai peranan penting bukan saja dalam rangka mendorong pertumbuhan perekonomian di daerah serta penambahan atau penghematan devisa, tetapi juga langsung terkait dengan pemenuhan kebutuhan pokok rakyat dan penyediaan lapangan kerja (Kennedy, 2013). Kelompok Tani Dewi Ratih 1 merupakan salah satu kelompok tani di Desa Maospati, Kecamatan Maospati, Kabupaten Magetan yang memiliki dua usahatani yang berbeda yaitu tanaman padi dan tebu. Berdasarkan buku inventaris kelompok tani bahwa di Kelompok Tani Dewi Ratih 1 terjadi peningkatan setiap tahunnya dari petani padi ke petani tebu. Tahun 2011 luas tanaman tebu sebesar 20 hektar kemudian mengalami peningkatan sebesar $(32,43 \%)$ sampai pada tahun 2015 dengan luas menjadi 39,2 hektar sedangkan padi pada tahun 2011 sebesar 38,2 hektar mengalami penurunan $(33,56 \%)$ tiap tahunnya hingga pada tahun 2015 menjadi 19 hektar. Banyak indikator untuk melihat keberhasilan menanam tebu diantaranya adalah karakteristik dan motivasi dalam menanam tebu. Karakteristik petani seperti umur, pendidikan formal, luas lahan, pendapatan, pengalaman usahatani, dan jumlah anggota rumah tangga mungkin mempunyai hubungan dengan motivasi dalam membudidayakan tanaman tebu. Pentingnya motivasi bukan saja dilihat dari segi luas tanah atau modal yang besar, tetapi juga dilihat dari segi lain, misalnya: harga, pemasaran yang mudah, pendapatan yang besar. Motivasi yang dimiliki oleh seorang petani akan turut mempengaruhi hasil dan pendapatan yang diperoleh, namun hendaknya motivasi petani haruslah diimbangi dengan memberikan penyuluhan yang dilakukan atau diberikan oleh pemerintah atau perusahaan yang menjadi mitra petani. Penyuluhan tersebut bertujuan untuk memberikan pandangan yang lebih, dalam hal berusaha tani tebu, yang akhirnya dapat lebih memotivasi para petani dalam berusahatani tebu. Berdasarkan uraian tersebut, maka menarik untuk dikaji mengenai tingkat motivasi serta hubungan karakteristik petani dengan motivasinya dalam membudidayakan tanaman tebu di Kelompok Tani Dewi Ratih 1 Desa Maospati, Kecamatan Maospati, Kabupaten Magetan.

\subsection{Rumusan Masalah}

Berdasarkan latar belakang diatas, maka dapat dirumuskan masalah sebagai berikut.

1) Bagaimanakah tingkat karakteristik petani di Kelompok Tani Dewi Ratih 1 Desa Maospati, Kecamatan Maospati, Kabupaten Magetan dalam membudidayakan tanaman tebu.

2) Bagaimanakah tingkat motivasi petani di Kelompok Tani Dewi Ratih 1 Desa Maospati, Kecamatan Maospati, Kabupaten Magetan dalam membudidayakan tanaman tebu. 
3) Bagaimanakah hubungan karakteristik petani dengan motivasinya dalam berusahatani tanaman tebu di Kelompok Tani Dewi Ratih 1 Desa Maospati, Kecamatan Maospati, Kabupaten Magetan.

\subsection{Tujuan Penelitian}

Tujuan yang ingin dicapai dalam penelitian ini sebagai berikut.

1) Mengetahui tingkat karakteristik petani di Kelompok Tani Dewi Ratih 1 Desa Maospati, Kecamatan Maospati, Kabupaten Magetan dalam membudidayakan tanaman tebu.

2) Mengetahui tingkat motivasi petani di Kelompok Tani Dewi Ratih 1 Desa Maospati, Kecamatan Maospati, Kabupaten Magetan dalam membudidayakan tanaman tebu.

3) Mengetahui hubungan karakteristik petani dengan motivasinya dalam berusahatani tanaman tebu di Kelompok Tani Dewi Ratih 1 Desa Maospati, Kecamatan Maospati, Kabupaten Magetan.

\section{Metode Penelitian}

\subsection{Metode dan Waktu Penelitian}

Penelitian ini dilaksanakan di Kelompok Tani Dewi Ratih 1, Desa Maospati Kecamatan Maospati, Kabupaten Magetan. Pemilihan lokasi ini dipilih dengan metode purposive. Penelitian dilaksanakan pada Desember 2016 sampai dengan Juni 2017.

\subsection{Jenis Data dan Sumber Data}

Jenis data yang digunakan dalam penelitian ini adalah data kuantitatif dan data kualitatif, sedangkan sumber data terdiri dari data primer dan data sekunder. Data kualitatif menjelaskan mengenai motivasi petani petani yang diperoleh dari keterangan ketua kelompok dan sampel dalam penelitian. Data kuantitatif berupa data jumlah petani di kelompok tani Dewi Ratih 1, data jumlah luas lahan sawah dan data lainnya yang berkaitan dengan penelitian ini. Data primer diperoleh dari hasil wawancara dengan responden di Kelompok Tani Dewi Ratih 1. Data sekunder meliputi data letak geografis dan topografi Desa Maospati, data luas wilayah dan tata guna lahan, komposisi penduduk di Desa Maospati, jumlah anggota Kelompok Tani Dewi Ratih 1, dan luas wilayah kelompok tani.

\subsection{Metode Pengumpulan Data}

Metode yang digunakan dalam penelitian ini dikumpulkan dengan menggunakan teknik wawancara, dokumentasi, dan observasi.

\subsection{Responden Penelitian}

Populasi dalam penelitian ini adalah seluruh petani yang membudidayakan tanaman tebu di Kelompok Tani Dewi Ratih 1 yang berjumlah 126 orang. 
Pengambilan sampel dalam penelitian ini menggunakan rumus Slovin dengan nilai batas toleransi kesalahan 10\% (Sevilla et al, 2007) sebanyak 56 orang dengan teknik simple random sampling.

\subsection{Variabel dan Metode Analisis}

Variabel dapat diartikan sebagai sesuatu yang menjadi objek pengamatan penelitian yang mempunyai nilai variasi (Antara, 2006). Variabel yang digunakan dalam penelitian ini adalah variabel karakteristik petani $(\mathrm{X})$ yang terdiri dari umur, pendidikan formal, pendapatan, luas lahan, jumlah anggota rumah tangga dan pengalaman usahatani. Variabel motivasi (Y) terdiri dari motivasi intrinsik dan motivasi ekstrinsik. Analisis data adalah proses mencari dan menyusun data yang diperoleh dari hasil wawancara, observasi secara sistematis sehingga mudah dipahami dan temuannya dapat diinformasikan kepada orang lain (Sugiyono, 2009). Analisis data yang digunakan adalah deskriptif dan analisis korelasi Rank Spearman.

\section{Hasil dan Pembahasan}

\subsection{Identitas Responden}

Identitas petani dalam penelitian ini meliputi jenis kelamin, umur, dan status pekerjaan usahatani yang dapat dilihat pada tabel 1 .

Tabel 1.

Distribusi Responden berdasarkan Identitas Responden

\begin{tabular}{|c|c|c|c|c|}
\hline \multirow[t]{2}{*}{ No } & \multirow[t]{2}{*}{ Identitas responden } & \multirow[t]{2}{*}{ Kategori } & \multicolumn{2}{|c|}{ Jumlah } \\
\hline & & & orang & $(\%)$ \\
\hline \multirow[t]{2}{*}{1} & Jenis kelamin & a. Laki-laki & 56 & 100,00 \\
\hline & & b. Perempuan & 0 & 0 \\
\hline \multirow[t]{2}{*}{2} & Umur & a. Usia produktif (15-64 th) & 42 & 75,00 \\
\hline & & $\begin{array}{l}\text { b. Usia non produktif ( } \geq 64 \\
\text { th) }\end{array}$ & 14 & 25,00 \\
\hline \multirow[t]{2}{*}{3} & Status pekerjaan & a. Pokok & 27 & 48,21 \\
\hline & usahatani & b. Sampingan & 29 & 51,79 \\
\hline
\end{tabular}

Sumber : Analisis data primer

Berdasarkan tabel 1 menunjukan jenis kelamin responden yang membudidayakan tanaman tebu seluruhnya adalah laki-laki dengan persentase $100 \%$. Hal ini dikarenakan jenis pekerjaan yakni sebagai petani membutuhkan tenaga yang lebih kuat, dimana aktivitas dalam pekerjaan ini lebih banyak dilakukan di sawah atau lahan usahatani. Umur responden tergolong usia produktif dengan persentase $75 \%$ yaitu antara usia (15-64th). Status pekerjaan usahatani termasuk dalam kategori pekerjaan sampingan dengan persentase $51,79 \%$. Besarnya jumlah responden yang menjadikan usahatani tebu sebagai pekerjaan sampingan menunjukan bahwa pendapatan di sektor pertanian (budidaya tanaman tebu) belum mampu memenuhi 
semua kebutuhan hidup mereka sehingga pekerjaan ini dapat dikatakan sebagai pekerjaan untuk mendapatkan pendapatan tambahan.

\subsection{Karakteristik Petani dalam Membudidayakan Tanaman Tebu}

Karakteristik petani yang digunakan dalam penelitian ini adalah umur, pendidikan formal, pendapatan, luas lahan, jumlah anggota rumah tangga, dan pengalaman usahatani. Distribusi responden yang berhubungan dengan motivasi petani dalam membudidayakan tanaman tebu dapat dilihat pada tabel 2 .

Tabel 2.

Distribusi Responden berdasarkan Karakteristik Petani di Kelompok Tani Dewi Ratih 1 Desa Maospati, Kecamatan Maospati, Kabupaten Magetan

\begin{tabular}{cllcc}
\hline No & \multicolumn{1}{c}{ Karakteristik petani } & \multicolumn{1}{c}{ Kategori } & \multicolumn{2}{c}{ Jumlah } \\
\cline { 3 - 5 } & & & Orang & $\%$ \\
\hline 1 & Umur & Sedang $(51,2-58,8)$ & 19 & 33,93 \\
2 & Pendidikan formal & Sedang (6,4-9,6 th) & 16 & 28,57 \\
3 & Pendapatan & Sangat rendah & 40 & 71,43 \\
& & (Rp.12.500.000 - & & \\
4 & Luas lahan & Rp.22.500.000 & & \\
& & Sangat sempit (0,25- & 40 & 71,43 \\
5 & Jumlah anggota & 0,45 Ha) & & \\
& tangga & Banyak (3,8-4,4 orang) & 16 & 28,57 \\
6 & Pengalaman usahatani & Sedang (10,6-15,4 th) & 20 & 35,71 \\
\hline
\end{tabular}

Sumber : Analisis data primer

Umur yang dicapai mayoritas responden termasuk kategori sedang dengan rata-rata 56,25 tahun dan masih tergolong usia produktif. Hasil ini sejalan dengan Mappiare (1983), ada kecenderungan bagi seseorang yang berusia 35 tahun ke atas untuk memantapkan dirinya dalam bekerja, berkenaan dengan semakin tigginya biaya hidup yang perlu dikeluarkan. Pendidikan formal menunjukan bahwa responden dominan memiliki riwayat pendidikan terakhir dengan kriteria sedang dengan rata-rata 9,46 tahun atau pernah menduduki bangku SLTP atau sederajat. Menurut Soekartawi (2003), bahwa banyaknya atau lamanya sekolah pendidikan yang diterima seseorang akan berpengaruh terhadap kecakapannya dalam pekerjaan tertentu. Pendapatan menunjukan bahwa responden memiliki pendapatan dengan kriteria sangat rendah dengan rata-rata Rp.19.416.642 per tahun. Hasil penelitian sejalan dengan Hermawanto (1993), yang menyatakan variasi pendapatan keluarga tergantung oleh beberapa faktor antara lain adalah faktor yang berhubungan dengan luas penguasaan lahan garapan, status kepemilikan lahan pertanian, jenis usaha atau cabang usahatani yang dikerjakan dan macam pekerjaan tambahan baik dari sektor pertanian maupun non pertanian. Luas lahan menunjukan bahwa sebagian besar responden memiliki luas penguasaan lahan dengan kriteria sangat sempit yakni 0,38 Ha. Menurut Mosher (1965), lahan merupakan sarana produksi bagi usahatani, 
termasuk salah satu faktor produksi dan pabrik hasil pertanian (dalam Damihartini dan Jahi, 2005).

Jumlah anggota rumah tangga menunjukan mayoritas responden memiliki jumlah anggota rumah tangga rata-rata 4 orang dengan kategori banyak. Menurut Arimbawa (2004), jumlah tanggungan rumah tanggungan rumah tangga menjadi motivasi untuk lebih giat lagi dalam berproduksi dan melakukan proses belajar. Pengalaman usahatani menunjukan mayoritas responden memiliki pengalaman usahatani tebu dengan kriteria kategori sedang rata-rata 13 tahun. Menurut Padmowihardjo (1994), mengemukakan bahwa pengalaman berusahatani memegang peranan penting dalam peningkatan kompetensi petani dalam proses belajar (dalam Damihartini dan Jahi, 2005).

\subsection{Motivasi Petani dalam Membudidayakan Tanaman Tebu}

Motivasi petani dalam membudidayakan tanaman tebu yang digunakan dalam penelitian meliputi motivasi intrinsik dan motivasi ekstrinsik. Menurut Maslow (1996), terdapat dua macam motivasi jika dilihat dari sumbernya, yaitu motivasi intrinsik dan ekstrinsik. Secara terperinci hasil rata-rata pencapaian skor mengenai tingkat motivasi petani di Kelompok Tani Dewi Ratih 1 Desa Maospati, Kecamatan Maospati, Kabupaten Magetan dalam membudidayakan tanaman tebu dapat dilihat pada tabel 3 .

Tabel 3.

Tingkat Motivasi Petani dalam Membudidayakan Tanaman Tebu di Kelompok Tani Dewi Ratih 1 Desa Maospati, Kecamatan Maospati, Kabupaten Magetan

\begin{tabular}{clcc}
\hline No & Variabel sumber motivasi & $\begin{array}{c}\text { Rata-rata pencapaian } \\
\text { skor }\end{array}$ & Kategori \\
\hline 1 & Motivasi Intrinsik & 3,35 & Sedang \\
2 & Motivasi Ekstrinsik & 3,42 & Tinggi \\
\hline & Tingkat Motivasi & 3,37 & Sedang \\
\hline
\end{tabular}

Tabel 3 menunjukan data hasil penelitian tingkat motivasi petani dalam membudidayakan tanaman tebu di Kelompok Tani Dewi Ratih 1 Desa Maospati, Kecamatan Maospati, Kabupaten Magetan termasuk kategori sedang, dengan pencapaian skor rata-rata sebesar 3,37. Skor ini didapat melalui penjumlahan ratarata motivasi intrinsik dan motivasi ekstrinsik.

Tingkat motivasi intrinsik petani dalam membudidayakan tanaman tebu di Kelompok Tani Dewi Ratih 1 Desa Maospati, Kecamatan Maospati, Kabupaten Magetan termasuk kategori sedang dengan pencapaian skor rata-rata 3,35. Motivasi intrinsik petani menunjukan adanya kebutuhan hidup petani yang belum terpenuhi atau belum puas dengan pemenuhan kebutuhan hidup mereka saat ini. Petani ingin mendapatkan hasil yang lebih besar lagi untuk memenuhi kebutuhan hidup mereka. Usahatani tebu dianggap mampu meningkatkan pendapatan petani, sehingga hasil penjualan dapat 
digunakan untuk kebutuhan sehari-hari yang belum terpenuhi. Tingkat motivasi ekstrinsik petani dalam membudidayakan tanaman tebu secara keseluruhan termasuk kategori tinggi dengan pencapaian skor rata-rata 3,42. Data ini menunjukan bahwa selain mendapat dorongan dari dalam dirinya, usahatani tebu yang dilakukan petani juga dikarenakan dorongan dari luar (orang lain). Tingginya kategori motivasi ekstrinsik yang dimiliki petani akan berpengaruh terhadap keberhasilan petani dalam membudidayakan tanaman tebu karena ada faktor-faktor atau pendorong dari luar diri petani. Motivasi ekstrinsik petani berasal dari ketua kelompok tani, PPL, petani lain, pedagang, dan petugas pabrik gula.

\subsection{Hubungan antara Karakteristik Petani dengan Motivasinya dalam Membudidayakan Tanaman Tebu di Kelompok Tani Dewi Ratih 1 Desa, Maospati, Kecamatan Maospati, Kabupaten Magetan.}

Analisis yang digunakan untuk mengetahui hubungan antara karakteristik petani yang mempengaruhi motivasi petani dalam membudidayakan tanaman tebu mencakup umur, pendidikan formal, luas lahan garapan, pendapatan rumah tangga, jumlah anggota rumah tangga, dan pengalaman usahatani dengan motivasi petani budidaya tanaman tebu. Analisis korelasi Rank Spearman dapat dilihat pada tabel 4.

Tabel 4.

Analisis Analisis Hubungan antara Karakteristik Petani Dengan Motivasi dalam Membudidayakan Tanaman Tebu di Kelompok Tani Dewi Ratih 1 Desa Maospati Kecamatan Maospati Kabupaten Magetan

\begin{tabular}{llccc}
\hline No & \multicolumn{1}{c}{ Korelasi } & rs & sig & Ket \\
\hline 1 & $\begin{array}{l}\text { Hubungan antara umur dengan motivasi } \\
2\end{array}$ & $\begin{array}{l}\text { Hubungan antara pendidikan formal } \\
\text { dengan motivasi }\end{array}$ & 0,104 & 0,024 \\
3 & $\begin{array}{l}\text { Hubungan antara pendapatan rumah } \\
\text { tangga dengan motivasi }\end{array}$ & $0,553^{* *}$ & 0,000 & $\mathrm{SS}$ \\
4 & $\begin{array}{l}\text { Hubungan antara luas lahan garapan } \\
\text { dengan motivasi }\end{array}$ & $0,553^{* *}$ & 0,000 & $\mathrm{SS}$ \\
5 & $\begin{array}{l}\text { Hubungan antara jumlah anggota rumah } \\
\text { tangga dengan motivasi }\end{array}$ & $0,400^{* *}$ & 0,002 & $\mathrm{SS}$ \\
6 & $\begin{array}{l}\text { Hubungan antara pengalaman usahatani } \\
\text { dengan motivasi }\end{array}$ & $0,370^{* *}$ & 0,005 & $\mathrm{SS}$ \\
\hline
\end{tabular}

Keterangan

SS $\left({ }^{* *}\right) \quad$ : Sangat signifikan dengan tingkat kepercayaan $a=0,01$

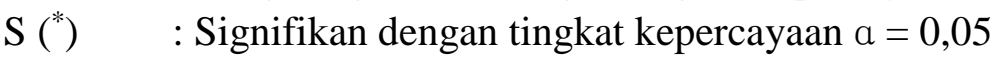

NS : Tidak signifikan/non signifikan

Tabel 4 dapat diketahui bahwa dari enam variabel tersebut yang memiliki hubungan antara karakteristik petani dengan motivasi yaitu umur, pendapatan rumah tangga, luas lahan garapan, jumlah anggota rumah tangga dan pengalaman usahatani. Menurut Usman dan Setyadi (2008), jika nilai $p<(a=0,05)$ maka terdapat hubungan 
nyata antara karakteristik petani dengan motivasi dalam membudidayakan tanaman tebu. Variabel pendidikan formal tidak memiliki hubungan dengan karakteristik petani dikarenakan nilai signifikansi yang diperoleh sebesar $0,448>(a=0,05)$

Analisis umur dengan motivasi petani dalam membudidayakan tanaman tebu memiliki hubungan yang signifikan dengan nilai koefisien korelasinya 0,300 dengan besar signifikansi $0,024<0,05$ pada taraf kepercayaan 95\% yang artinya bahwa hubungan antara umur dengan motivasi memiliki korelasi yang cukup kuat atau berada pada kisaran (>0,25 - 0,5). Analisis hubungan antara pendidikan formal dengan motivasi dapat diketahui bahwa tidak adanya korelasi antara pendidikan formal dengan motivasi, dimana rs yang dihasilkan sebesar 0,104 sedangkan nilai signifikansinya sebesar 0,448 > 0,05 yang artinya tidak terdapat hubungan yang nyata antara pendidikan formal dengan motivasi petani dalam membudidayakan tanaman tebu. Semakin tinggi atau rendahnya pendidikan formal tidak berhubungan dengan tingkat motivasi petani dalam membudidayakan tanaman tebu. Pendapatan rumah tangga dengan motivasi memiliki korelasi dengan kategori kuat, dimana rs yang dihasilkan sebesar 0,553 atau berada pada kisaran $(>0,5-0,75)$, sedangkan nilai signifikansinya $0,000<0,001$ pada taraf kepercayaan $99 \%$ yang dapat disimpulkan bahwa hasil analisis menunjukan adanya hubungan yang sangat signifikan atau nyata antara pendapatan rumah tangga petani dengan motivasi petani dalam membudidayakan tanaman tebu dimana semakin tinggi tingkat pendapatan akan sejalan dengan tingginya tingat motivasi petani dalam membudidayakan tanaman tebu.

Luas lahan garapan dengan motivasi dalam membudidayakan tanaman tebu memiliki korelasi dengan kategori kuat dengan nilai koefisien korelasinya sebesar 0,553 pada kisaran $(>0,5-0,75)$, dengan besar signifikansinya $0,000<0,01$ pada taraf kepercayaan 99\%. Hasil analisis menunjukan bahwa ada hubungan yang signifikan atau nyata dengan kategori kuat antara luas lahan garapan dengan motivasi dalam membudidayakan tanaman tebu mengindikasikan bahwa semakin tinggi luas lahan garapan maka akan sejalan dengan tingginya tingkat motivasi petani dalam membudidayakan tanaman tebu. Jumlah anggota rumah tangga dengan motivasi memiliki korelasi dengan kategori cukup kuat, dimana rs yang dihasilkan sebesar 0,400 atau berada pada kisaran $(>0,25-0,50)$, sedangkan nilai signifikansinya 0,002 $<0,001$ pada taraf kepercayaan 99\% yang dapat disimpulkan bahwa hasil analisis menunjukan adanya hubungan yang sangat signifikan atau nyata antara jumlah anggota rumah tangga petani dengan motivasi petani dalam membudidayakan tanaman tebu dimana semakin tinggi jumlah anggota rumah tangga maka akan sejalan dengan tingginya tingat motivasi petani dalam membudidayakan tanaman tebu. Analisis hubungan antara pengalaman usahatani dengan motivasI dapat diketahui bahwa adanya hubungan yang nyata antara pengalaman usahatani dengan motivasi petani dalam membudidayakan tanaman tebu dengan nilai koefisien korelasi sebesar 0,370 pada kisaran $(>0,25-0,50)$ sedangkan nilai signifikansi sebesar $0,005<0,01$ pada taraf kepercayaan 99\%. Hasil analisis menunjukan bahwa ada 
hubungan yang signifikan atau nyata dengan kategori cukup kuat antara pengalaman usahatani dengan motivasi dalam membudidayakan tanaman tebu yang mengindikasikan bahwa semakin tinggi pengalaman usahatani maka akan sejalan dengan tingginya tingkat motivasi petani dalam membudidayakan tanaman tebu.

\section{Simpulan dan Saran}

\subsection{Simpulan}

Hasil dari penelitian ini secara umum untuk karakteristik petani yang meliputi umur berada pada kategori sedang, pendidikan formal kategori sedang, pendapatan rumah tangga kategori sangat rendah, luas lahan garapan kategori sangat sempit, jumlah anggota rumah tangga kategori banyak, dan pengalaman usahatani kategori sedang. Tingkat motivasi petani yang membudidayakan tanaman tebu di Kelompok Tani Dewi Ratih 1 Desa Maospati, Kecamatan Maospati, Kabupaten Magetan termasuk dalam kategori sedang. Hubungan karakteristik petani yang mempengaruhi motivasi petani dalam membudidayakan tanaman tebu secara signifikan adalah umur, pendapatan, luas lahan, jumlah anggota rumah tangga, dan pengalaman usahatani yang berarti semakin tinggi karakteristik petani yaitu umur, pendapatan, luas lahan, jumlah anggota rumah tangga, dan pengalaman usahatani maka tingkat motivasi petani dalam membudidayakan tanaman tebu juga akan semakin tinggi.

\subsection{Saran}

Saran yag dapat diajukan dalam penelitian ini sebagai berikut.

1. Anggota Kelompok Tani Dewi Ratih 1 diharapkan agar lebih semangat dalam berusahatani tebu meskipun belum cukup terpenuhinya kebutuhan akan penghargaan dan lebih mempertimbangkan lagi kebutuhan pokok sebelum memenuhi kebutuhan yang jenjangnya lebih tinggi.

2. PPL perlu lebih intensif berkontribusi dalam memberikan informasi yang relevan dengan menempatkan posisinya sebagai fasilitator serta aktif melakukan pendampingan pada petani agar dapat memanfaatkan peluang dan pelatihan usaha bisnis tanaman tebu sehingga berdampak pada peningkatan pendapatan petani.

3. Ketua Kelompok Tani Dewi Ratih 1 diharapkan mendorong anggotanya agar lebih termotivasi dalam membudidayakan tanaman tebu terutama kepada petanipetani baru yang masih muda sehingga mereka lebih tertarik terjun ke bidang pertanian khususnya usahatani tebu mengingat banyak anggota kelompok tani yang baru.

\section{Ucapan Terimakasih}

Terimakasih kepada semua pihak yang telah memberikan pengarahan, bimbingan serta dukungan dalam penyelesaian penelitian sehingga dapat termuat ejurnal ini. Semoga penelitian ini dapat bermanfaat sebagaimana mestinya. 


\section{Daftar Pustaka}

Antara, M. 2006. Bahan Ajar Mata Kuliah Metode Penelitian Agribisnis. Program Studi Magister Agribisnis, Program Pasca Sarjana Universitas Udayana: Denpasar

Arimbawa, P. 2004. Peran Kelompok untuk Meningkatkan Kemampuan Anggota dalam Penerapan Inovasi Teknologi. Bogor : Institut Pertanian Bogor.

Damihartini, Rini Sri Dan Jahi, Amri. 2005. Hubungan Karakteristik Petani dengan Kompetensi Agribisnis pada Usahatani Sayuran di Kabupaten Kediri Jawa Timur. $2005 . \quad$ Volume $1, \quad$ No.1. http://Mail.Student.Ipb.Ac.Id/Index.Php/Jupe/Article/Viewfile/2097/1128.pdf

Hermawanto VR. 1993. Hubungan Karakteristik Petani yang Menanam Varietas Unggul Lokal dan Persepsi Mereka tentang Varietas Tersebut di Desa Gledek Kabupaten Klaten Jawa Tengah dan Desa Jambudepa Kabupaten Cianjur Jawa Barat. [Tesis] Sekolah Pascasarjana Institute Pertanian Bogor. Bogor. http://repository.ipb.ac.id.

Kennedy, John. 2013. Efikasi Herbisida Ametrin untuk Mengendalikan Gulma pada Pertanaman Tebu (Saccharum Officinarum L) di Kabupaten Lampung Lahan Kering. Skripsi. Lampung

Mappiare. 1983. Psikologi Orang Dewasa. Usaha Nasional:Surabaya

Maslow, Abraham. 1996. Motivasi dan Kepribadian 1 (Teori Motivasi dan Pendekatan Hierarki Kebutuhan Manusia). PT.PBP. Jakarta

Sevilla. C. G. 2007. Research Methods. Rex Printing Company: Quezo City

Soekartawi. 2003. Prinsip Ekonomi Pertanian. Rajawali Press. Jakarta

Sugiyono. 2009. Penelitian Kualitatif. Afabeta. Bandung

Usman, Husaini dan Akbar, R. Purnomo Setiady. 2008. Pengantar Statistika Bumi Aksara. Jakarta 